AperTO - Archivio Istituzionale Open Access dell'Università di Torino

\title{
A MODEL STUDY ON THE ABSORBED DOSE OF RADIATION FOLLOWING RESPIRATORY INTAKE OF 238 U308 AEROSOLS
}

\section{This is the author's manuscript}

Original Citation:

Availability:

This version is available http://hdl.handle.net/2318/156588

since 2016-01-08T11:13:58Z

Published version:

DOI:10.1093/rpd/ncu034

Terms of use:

Open Access

Anyone can freely access the full text of works made available as "Open Access". Works made available under a Creative Commons license can be used according to the terms and conditions of said license. Use of all other works requires consent of the right holder (author or publisher) if not exempted from copyright protection by the applicable law. 


\title{
A MODEL STUDY ON THE ABSORBED DOSE OF RADIATION FOLLOWING RESPIRATORY INTAKE OF ${ }^{238} \mathrm{U}_{3} \mathrm{O}_{8}$ AEROSOLS
}

\author{
Carlo Canepa \\ Dipartimento di Chimica, Università di Torino, Via Pietro Giuria 7, 10125 Torino, Italy \\ Corresponding author. Tel.: +390116707530. \\ E-mail address: carlo.canepa@unito.it
}

\begin{abstract}
Aerosols of depleted uranium oxides, formed upon high-energy impact of shells on hard targets during military operations, are able to disperse, reach the alveolar region of the lungs and be absorbed and distributed throughout various parts of the body. The absorbed particles are subjected to clearance in the upper respiratory tract, distribution to other body districts, dissolution, and excretion. While the soluble forms of uranium are known to deliver a small dose of radiation to the body due to their homogeneous distribution and the low specific activity of ${ }^{238} \mathrm{U}$, ceramic particles exhibit a low dissolution rate and irradiate a limited volume of tissue for a long time with $\alpha$ particles with energy $4.267 \mathrm{MeV}$. The extent of the irradiated tissues depends on the radius of the particles and the total intake of uranium oxides. For the measured intake of $\mathrm{U}_{3} \mathrm{O}_{8}$ of a war veteran $(15.51 \mu \mathrm{g})$ the number of particles ranges from $5.56 \times 10^{4}$ to $6.95 \times 10^{6}$ for sizes of $0.4-$ $2.0 \mu \mathrm{m}$. Modeling the distribution of the particles between two compartments of the body, the averaged dose absorbed in 20 years by tissues surrounding the particles and within the range of the $\alpha$ particles varies from $6.8 \mathrm{mGy}$ to 0.85 Gy for lungs and $8.1 \mathrm{mGy}$ to 1.0 Gy for the lymph nodes, respectively. Correspondingly, due to the clearance and redistribution, the mass irradiated by $2.0 \mu \mathrm{m}$ particles falls in 20 years from $6.06 \mathrm{mg}$ to $0.94 \mu \mathrm{g}$ in the lungs and grows from zero to 1.0 $\mathrm{mg}$ in the lymph nodes. The estimated rate of formation of hydroxyl radicals upon radiolysis of water in the lungs and lymph nodes is $5.17 \times 10^{4} \mathrm{~d}^{-1}$ per cell after one year.
\end{abstract}

Keywords: depleted uranium; particles distribution; absorbed dose 


\section{INTRODUCTION}

Depleted uranium (DU) is characterized by a reduced content of the isotope ${ }^{235} \mathrm{U}$ with respect to natural uranium and is obtained as a by-product of the enrichment process of natural and reprocessed uranium. It is used in military combat in various projectiles because it is readily available, pyrophoric, and it has a unique armor-piercing capability due to its high density. Upon high-energy impact, the shells of DU heat up, fragment and oxidize into a mixture of uranium oxides with various oxidation states ${ }^{(1)}$, usually dominated by $\mathrm{U}_{3} \mathrm{O}_{8}$. The dispersed ceramic particles of DU oxides with sizes of the order of $1 \mu \mathrm{m}$ are able to reach the alveolar region of the lungs upon inhalation. Whether the biological effects following the exposure to aerosols of DU oxides are responsible for the complex syndrome affecting the military and civilian populations around combat areas is still a matter of controversy ${ }^{(2,3,4,5)}$. The long half-life of the isotope ${ }^{238} \mathrm{U}\left(\tau_{1 / 2}=4.468 \times\right.$ $10^{9} \mathrm{yr}$ ) makes its specific activity relatively low, and it is easy to show that the dose absorbed by the people exposed to DU aerosols is a small fraction of the background radiation. However, it is difficult to reconcile the low estimate of the radiation dose delivered to the whole body by the intake of depleted uranium ${ }^{(6,7,8,9)}$ and the reports of the complex array of symptoms affecting war veterans and civilian populations, however anecdotal.

As a contribution to this issue, this work points out the small portion of an idealized body affected by the radiation delivered by a mass $m_{0}$ of $\mathrm{U}_{3} \mathrm{O}_{8}$ (molecular mass $\mu=0.8421 \mathrm{~kg} \mathrm{~mol}^{-1}$, density $\rho_{\mathrm{U}_{3} \mathrm{O}_{8}}=8326 \mathrm{~kg} \mathrm{~m}^{-3}$ ) in the form of particles of initial radius $r_{0}$, containing exclusively the isotope ${ }^{238} \mathrm{U}$. It will be shown that depleted uranium particles are able to deliver a much higher radiation dose with respect to the soluble forms of uranium, albeit to a small mass of tissue.

The actual distribution of ${ }^{238} \mathrm{U}$ following an instantaneous respiratory intake of ceramic particles of $\mathrm{U}_{3} \mathrm{O}_{8}$ was modeled by Valdés ${ }^{(10)}$, who described how the species containing ${ }^{238} \mathrm{U}$ distribute among lungs, lymph nodes, kidneys, bones, blood, and other tissues and are eventually excreted via the urine. The model developed in this work computes the amount of radiation absorbed by the tissue surrounding the particles in the two compartments of the body where the ceramic oxide particles mostly reside, i.e. the lungs and the lymph nodes. To partition the cumulative dose affecting all the different body compartments, one would have to solve a complete set of differential equations representing all fluxes among the compartments.

The calculation of the absorbed dose does not include the contribution from the beta decay of daughter radionuclides ${ }^{234} \mathrm{Th}\left(\tau_{1 / 2}=24.10 \mathrm{~d}, \lambda=3.3288 \times 10^{-7} \mathrm{~s}^{-1}, \beta^{-} 0.0592 \mathrm{MeV}\right)$ and ${ }^{234 \mathrm{~m}} \mathrm{~Pa}\left(\tau_{1 / 2}=1.159 \mathrm{~min}, \lambda=9.9676 \times 10^{-3} \mathrm{~s}^{-1}, \beta^{-} 0.82 \mathrm{MeV}\right)$, in secular equilibrium with ${ }^{238} \mathrm{U}$ $\left(\lambda=4.9160 \times 10^{-18} \mathrm{~s}^{-1}, \alpha 4.267 \mathrm{MeV}\right)$ through the first three steps of the decay chain of ${ }^{238} \mathrm{U}$

$$
{ }^{238} \mathrm{U} \stackrel{\alpha}{\rightarrow}{ }^{234} \mathrm{Th} \stackrel{\beta^{-}}{\rightarrow}{ }^{234 \mathrm{~m}} \mathrm{~Pa} \stackrel{\beta^{-}}{\rightarrow}{ }^{234} \mathrm{U} .
$$

The contribution of the gamma emissions, the possible presence of ${ }^{236} \mathrm{U}$, heavier actinides, and the residual ${ }^{235} \mathrm{U}$ in the particles are also neglected.

\section{RESULTS AND DISCUSSION}

We begin by taking into consideration the $13.153 \mu \mathrm{g}$ intake of ${ }^{238} \mathrm{U}$ of a Persian Gulf War I veteran estimated by Valdés ${ }^{(10)}$ from the analysis of a urine sample. This value is bracketed by the estimated $100 \mu \mathrm{g}$ intake in the neighborhood of a burning tank hit by a $120 \mathrm{~mm}$ DU projectile and the corresponding intake of $0.8 \mu \mathrm{g}$ at a distance of $200 \mathrm{~m}$ from the impact site ${ }^{(11)}$. At the breathing rate of $0.9 \mathrm{~m}^{3} \mathrm{~h}^{-1}$ in a contaminated area with a DU air concentration of $1 \mu \mathrm{g} \mathrm{m}^{-3}$, the assumed exposure of $13.153 \mu \mathrm{g}$ would be reached in $17.23 \mathrm{~h}$. The corresponding mass of $\mathrm{U}_{3} \mathrm{O}_{8}$ is $m_{0}=$ $15.508 \mu \mathrm{g}$. As we shall see, the mass of ${ }^{238} \mathrm{U}$ in the body is time-dependent because of the excretion 
mechanisms acting after the exposure, and we indicate the instantaneous value of the mass with $m$. The number of ${ }^{238} \mathrm{U}$ nuclei at any given time is thus

$$
N_{U}=3 \frac{m}{\mu} N_{A}
$$

(3 being the number of ${ }^{238} \mathrm{U}$ nuclei in each molecule of $\mathrm{U}_{3} \mathrm{O}_{8}$ ) and, at $t=0$, we have $N_{U}=$ $3.3271 \times 10^{16}$, corresponding to the activity $\lambda N_{U}=0.1636 \mathrm{~Bq}$. The average distance between $n$ sources of $\alpha$ particles distributed in a body mass $M_{b}$ is

$$
d \cong\left(\frac{M_{b}}{\rho_{w} n}\right)^{1 / 3}
$$

If the uranium is in a soluble form, like a uranyl salt, we would have $n=N_{U}$, and the distribution in the body of both the ${ }^{238} \mathrm{U}$ and its $\alpha$ radiation may be considered homogeneous over the whole mass. In fact, for $M_{b}=70 \mathrm{~kg}$, the average distance between ${ }^{238} \mathrm{U}$ nuclei would be $1.28 \mu \mathrm{m}$, smaller than the range $R$ of the $\alpha$ particles themselves, $29.63 \mu \mathrm{m}$ (ASTAR database) ${ }^{(12)}$.

The power transferred to the body by the decay of ${ }^{238} \mathrm{U}$ is $P=\lambda N_{U} E_{\alpha}=1.12 \times 10^{-13} \mathrm{~W}$, where

$$
E_{\alpha}=4.267 \mathrm{MeV} \times 1.602 \times 10^{-13} \mathrm{~J} \mathrm{MeV}^{-1}=6.8325 \times 10^{-13} \mathrm{~J}
$$

is the energy per nuclear disintegration. The corresponding delivered dose rate $\psi$ is $P$ divided by the mass of the irradiated tissue, with units of a specific power, Gy d $\mathrm{d}^{-1}$. If the energy in Eq. (3) is multiplied by the corresponding weight factor for $\alpha$ particles (20), we obtain the effective dose rate in $\mathrm{Sv} \mathrm{d}^{-1}$. Neglecting the effect of the relatively short biological half-life of soluble forms of uranium in the human body $(\approx 1 \mathrm{~d})$, we obtain that the dose delivered to the body $\left(M_{b}=70 \mathrm{~kg}\right)$ by the homogeneous distribution is $1.01 \times 10^{-6} \mathrm{~Sv} \mathrm{yr}^{-1}$, a small fraction of the average background radiation dose of $2-3 \times 10^{-3} \mathrm{~Sv} \mathrm{yr}^{-1}$. This approximate result corresponds to $6.16 \times$ $10^{-6} \mathrm{~Sv} \mathrm{~Bq}^{-1}$ for one year, in agreement with the reported value of the effective absorbed dose following a hypothetical single acute inhalation of $\left.90 \mathrm{~Bq}\left(6.0 \times 10^{-6} \mathrm{~Sv} \mathrm{~Bq}\right)^{-1}\right)^{(7)}$. The corresponding dose conversion factor is $6.5 \times 10^{-5} \mathrm{~Sv} \mathrm{mg}^{-1} \mathrm{yr}^{-1}$, about one half of the accurate value $1.2 \times 10^{-4} \mathrm{~Sv} \mathrm{mg}^{-1} \mathrm{yr}^{-1}(11)$.

On the other hand, if the particles are in the form of spheres of $\mathrm{U}_{3} \mathrm{O}_{8}$ with initial radius $r_{0}$, their number $N_{0}$ would be related to the mass by

$$
m_{0}=N_{0} \rho_{\mathrm{U}_{3} \mathrm{O}_{8}} \frac{4}{3} \pi r_{0}^{3}
$$

The number of particles $N_{0}$ (listed in Table 1) for initial radius $0.4 \leq r_{0} \leq 2.0 \mu \mathrm{m}$ is $5.56 \times 10^{4} \leq$ $N_{0} \leq 6.95 \times 10^{6}$. In this case, $n=N_{0}$ and the average distance between the $\alpha$ sources according to Eq. (2) is $2.16 \times 10^{3} \leq d \leq 1.08 \times 10^{4} \mu \mathrm{m}, 2-3$ orders of magnitude larger than the range of the $\alpha$ particles. Consequently, the distribution of ${ }^{238} \mathrm{U}$ in the body may not be considered homogeneous, each particle delivering its radiation only to a sphere of radius $R=29.63 \mu \mathrm{m}$ and mass $M_{\alpha}=$ $\rho_{w}(4 / 3) \pi R^{3}$. Since the range of the $\alpha$ particles emitted by ${ }^{238} \mathrm{U}$ in uranium $(7.46 \mu \mathrm{m})$ exceeds the size of the particles, we do not correct for self-absorption. In this case the absorbed energy is not distributed to the whole body, but limited by the range of the $\alpha$ particles to the time-dependent mass

$$
M=N M_{\alpha}
$$


where we have identified the body density with the density of water $\rho_{w}$. Typical values of $M_{0}$ are a fraction of a gram. The irradiated energy will be averaged over the limited portions of the organs directly affected by the $\alpha$ radiation. This approach leads to considerably higher doses with respect to the standard methods, which assess doses by averaging over the whole tissue mass. The initial dose rate delivered by $N_{0}$ particles thus is

$$
\psi_{0}=\lambda \frac{3 m_{0} N_{A}}{\mu} \frac{E_{\alpha}}{N_{0} M_{\alpha}}
$$

independent of the number of the particles since the ratio $m_{0} / N_{0}$ depends only on $r_{0}$ and the density of the material, according to Eq. (4). The range of the initial dose rate for $0.4 \leq r_{0} \leq$ $2.0 \mu \mathrm{m}$ is $9.32 \times 10^{-2} \leq \psi_{0} \leq 11.6 \mathrm{~Sv} \mathrm{yr}^{-1}$, to be compared to $1.01 \times 10^{-6} \mathrm{~Sv} \mathrm{yr}^{-1}$ for the homogeneous system. Since the dissolved fraction of $\mathrm{U}_{3} \mathrm{O}_{8}$ gives a negligible contribution to the radiation dose, we only keep track of the uranium still present in the body as undissolved particles. The particles are assumed to distribute in two compartments: the lungs, where the particles are subjected to both dissolution and clearance, and the interstitium and lymph nodes, identified by Valdés ${ }^{(10)}$ as the main repository of undissolved particles, where the particles are only subjected to dissolution. The transport of the particles from the lungs into the lymph nodes exhibits the rate coefficient $\lambda_{a}=2.0 \times 10^{-4} \mathrm{~d}^{-1}$, while the clearance towards the mucociliary escalator takes place with the rate coefficient $\lambda_{c}=1.0 \times 10^{-3} \mathrm{~d}^{-1}{ }^{(10)}$, both processes being mediated by the alveolar macrophages.

Since the particles dissolve over time regardless of their location, their number is actually timedependent. To compute the amount of undissolved $\mathrm{U}_{3} \mathrm{O}_{8}$ taking into account the dissolution rate of $\mathrm{U}_{3} \mathrm{O}_{8}$ particles, we follow the process as described by Chazel et al., ${ }^{(7)}$ that is the sum of a rapidly dissolving fraction $f$ with rate coefficient $\lambda_{1}$ and a slowly dissolving fraction $1-f$ with rate coefficient $\lambda_{2}$. We thus have two sets of rate coefficients: the transport coefficients $\lambda_{a}$ and $\lambda_{c}$, governing the transfer of particles, and the dissolution coefficients $\lambda_{1}$ and $\lambda_{2}$, that remove uranium from the particles. The relevant differential equations for transport and dissolution (two for the rapidly-dissolving fractions, $x_{1}$ and $y_{1}$, and two for the slowly-dissolving fractions, $x_{2}$ and $y_{2}$, where $x$ and $y$ represent the mass of $\mathrm{U}_{3} \mathrm{O}_{8}$ in lungs and lymph nodes, respectively) are

$$
\dot{x}_{i}=-\left(\lambda_{c}+\lambda_{a}+\lambda_{i}\right) x_{i}
$$

with solution

$$
m_{x} / m_{0}=s\left(u_{1}+u_{2}\right)
$$

where

$$
\begin{gathered}
m_{x}=x_{1}+x_{2}, \quad s=e^{-\left(\lambda_{c}+\lambda_{a}\right) t}, \\
u_{1}=f e^{-\lambda_{1} t}, \quad u_{2}=(1-f) e^{-\lambda_{2} t} .
\end{gathered}
$$

For the rapidly and slowly-dissolving fraction in the lymph nodes $\left(y_{i}\right)$

$$
\dot{y}_{i}=\lambda_{a} x_{i}-\lambda_{i} y_{i}
$$

with solution 


$$
m_{y} / m_{0}=\frac{\lambda_{a}}{\lambda_{c}+\lambda_{a}}(1-s)\left(u_{1}+u_{2}\right)
$$

where $m_{y}=y_{1}+y_{2}$. Plots of $m_{x} / m_{0}$ and $m_{y} / m_{0}$ versus time are shown in Fig. 1. The values of the rapidly dissolving fraction and of the dissolution coefficients are $f=0.57, \lambda_{1}=0.07 \mathrm{~d}^{-1}$, and $\lambda_{2}=3.4 \times 10^{-4} \mathrm{~d}^{-1}$, indicating a biological half-life of the slow-dissolving fraction of $5.58 \mathrm{yr}$. For comparison, the rate coefficient for the dissolution of $\mathrm{U}_{3} \mathrm{O}_{8}$ particles in alveolar macrophages given by Poncy et al. ${ }^{(13)}$ is $3.9 \times 10^{-4} \mathrm{~d}^{-1}$. Thus the total mass $m=m_{x}+m_{y}$ in the form of particles is

$$
m / m_{0}=\frac{s \lambda_{c}+\lambda_{a}}{\lambda_{c}+\lambda_{a}}\left(u_{1}+u_{2}\right)
$$

exhibiting a mean life for the slowly-dissolving fraction approximately equal to $\left(\lambda_{c}+\lambda_{a}+\right.$ $\left.\lambda_{2}\right)^{-1}=1.78$ yr. Defining

$$
v_{1}=\frac{f-s u_{1}}{\lambda_{c}+\lambda_{a}+\lambda_{1}}, \quad v_{2}=\frac{1-f-s u_{2}}{\lambda_{c}+\lambda_{a}+\lambda_{2}}
$$

the corresponding cleared and dissolved fractions of the initial intake are $\lambda_{c}\left(v_{1}+v_{2}\right)$ and $\left(\lambda_{a} /\left(\lambda_{c}+\lambda_{a}\right)\right)\left(1-u_{1}-u_{2}+\lambda_{1} v_{1}+\lambda_{2} v_{2}\right)$, respectively. The excretion of the uranium content of the body after dissolution is almost exclusively urinary, and its distribution was modeled by Wrenn et al. ${ }^{(14)}$. According to the model presented here, the total normalized dissolution rate is $\left(\lambda_{c}+\lambda_{a}\right)^{-1}\left(\left(s \lambda_{c}+\lambda_{a}\right) \lambda_{1} u_{1}+\lambda_{a} \lambda_{2} u_{2}\right)$, starting at $4 \times 10^{-2} \mathrm{~d}^{-1}$ at $t=0$ and rapidly dropping to $4 \times 10^{-5} \mathrm{~d}^{-1}$ after 110 days.

The irradiated mass was computed for each compartment according to Eq. (5) with the timedependent number of particles given by

$$
\begin{gathered}
\dot{N}_{x}=-\left(\lambda_{c}+\lambda_{a}\right) N_{x}, \\
\dot{N}_{y}=\lambda_{a} N_{x},
\end{gathered}
$$

with solutions

$$
\begin{gathered}
N_{x} / N_{0}=s, \\
N_{y} / N_{0}=\frac{\lambda_{a}}{\lambda_{c}+\lambda_{a}}(1-s),
\end{gathered}
$$

and

$$
N / N_{0}=\frac{s \lambda_{c}+\lambda_{a}}{\lambda_{c}+\lambda_{a}}
$$

The quantities $N_{x} / N_{0}$ and $N_{y} / N_{0}$ are shown in Fig. 2, and the corresponding masses $M_{x}$ and $M_{y}$ are obtained multiplying by the mass of tissue $M_{\alpha}$ irradiated by a single particle. The result reproduces Valdés' observation that a fraction $\sim 10 \%$ of the initial intake is permanently sequestered in the lymph nodes. The values of $M_{x}$ and $M_{y}$ reported in Tables $\mathbf{2}$ and $\mathbf{3}$ depend on $N_{0}$, and we can see that the amount of irradiated mass differ considerably in the two compartments. 
The time-dependent dose rates delivered to the two compartments $(z=x, y)$ according to Eqs. (8) and (10) are

$$
\psi_{z} / \psi_{0}=u_{1}+u_{2}
$$

with the specific dose rate at $t=0$ defined by Eq. (6). The dose rate delivered to the lungs and lymph nodes is the sum of two exponentials, decreasing in time from the initial value $\psi_{0}$, as shown in Fig. 3. The dose rate at $t=0$ is reported in Table 1 for specific values of the initial radius of the particles, along with the number of irradiated cells assuming a cell number density $\rho_{c}=1.43 \times$ $10^{10}$ cell $\mathrm{kg}^{-1}$. With this value of the cell number density, we obtain the constant ratio 1.56 cells/particle. The initial content $m_{0}$ of ${ }^{238} \mathrm{U}$ in the body and the size of the particles determine the extent of the irradiated mass $M_{z}$ in each compartment, the radiation being delivered to only a small amount of tissue for a prolonged period of time. Both in the lungs and the lymph nodes the full $20 \mathrm{yr}$ dose from particles of size $2 \mu \mathrm{m}$ is absorbed by $\sim 1 \mathrm{mg}$.

The total dose is independent of the number of particles (as is $\psi_{0}$ ) and of the transport coefficients, and is obtained by integration of the dose rate as

$$
D_{z}=\int_{0}^{t} \psi_{z}(\xi) d \xi
$$

affording the expression

$$
D_{z} / \psi_{0}=\lambda_{1}^{-1}\left(f-u_{1}\right)+\lambda_{2}^{-1}\left(1-f-u_{2}\right)
$$

for each compartment. In the absence of both transport and dissolution we would have $D_{z} / \psi_{0}=t$. The plot of Eq. (19) in Fig. 4 shows that after $5 \mathrm{yr}$ the dose reaches $0.12 \mathrm{~Gy}$, reaching 0.25 Gy after $30 \mathrm{yr}$. An average quantity that takes into account the extent of the irradiated tissue in each compartment would be

$$
<D_{z}>=\int_{0}^{t} \psi_{z} \frac{N_{z}}{N} d \xi
$$

in the assumption that the dissolved forms of ${ }^{238} \mathrm{U}$ are rapidly excreted and only the surviving particles contribute significantly to the total radiation dose. The averaged dose defined by Eq. (20) correctly depends on both the transport and dissolution rate coefficients, and the total dose $D_{z}$ is partitioned in the two compartments, since $\left\langle D_{x}\right\rangle+\left\langle D_{y}\right\rangle=D_{z}$.

The averaged dose could also be defined with respect to the initial number of particles $N_{0}$, affording

$$
<D_{x}>=\int_{0}^{t} \psi_{x} \frac{N_{x}}{N_{0}} d \xi=\psi_{0}\left(v_{1}+v_{2}\right)
$$

and

$$
<D_{y}>=\int_{0}^{t} \psi_{y} \frac{N_{y}}{N_{0}} d \xi=\psi_{0}\left[\lambda_{a}\left(\frac{v_{1}}{\lambda_{1}}+\frac{v_{2}}{\lambda_{2}}\right)-\frac{\lambda_{a}}{\lambda_{c}+\lambda_{a}}(1-s)\left(\frac{u_{1}}{\lambda_{1}}+\frac{u_{2}}{\lambda_{2}}\right)\right]
$$


However, in this case the sum $\left\langle D_{x}\right\rangle+\left\langle D_{y}>\right.$ would not amount to $D_{z}$ as defined by Eq. (19) and the definition making use of the weight $N_{z} / N_{0}$ would give an unrealistically small averaged dose in both compartments for a large clearance rate (large $\lambda_{c}$ ), since

$$
\begin{gathered}
\lim _{\lambda_{c} \rightarrow \infty} \frac{N_{x}}{N_{0}}=\lim _{\lambda_{c} \rightarrow \infty} e^{-\left(\lambda_{c}+\lambda_{a}\right) t}=0, \\
\lim _{\lambda_{c} \rightarrow \infty} \frac{N_{y}}{N_{0}}=\lim _{\lambda_{c} \rightarrow \infty} \frac{\lambda_{a}}{\lambda_{c}+\lambda_{a}}\left(1-e^{-\left(\lambda_{c}+\lambda_{a}\right) t}\right)=0,
\end{gathered}
$$

while

$$
\lim _{\lambda_{c} \rightarrow \infty} \frac{N_{x}}{N}=\lim _{\lambda_{c} \rightarrow \infty} \frac{\left(\lambda_{c}+\lambda_{a}\right) e^{-\left(\lambda_{c}+\lambda_{a}\right) t}}{\lambda_{c} e^{-\left(\lambda_{c}+\lambda_{a}\right) t}+\lambda_{a}}=0
$$

and

$$
\lim _{\lambda_{c} \rightarrow \infty} \frac{N_{y}}{N}=\lim _{\lambda_{c} \rightarrow \infty} \frac{\lambda_{a}\left(1-e^{-\left(\lambda_{c}+\lambda_{a}\right) t}\right)}{\lambda_{c} e^{-\left(\lambda_{c}+\lambda_{a}\right) t}+\lambda_{a}}=1
$$

giving $\lim _{\lambda_{c} \rightarrow \infty}<D_{y}>=D_{y}$. For this reason we choose to compute the average doses with Eq. (20).

In this work, the dose rate $\psi_{z}$, the dose $D_{z}$, and the averaged dose $\left\langle D_{z}\right\rangle$ are all computed for an irradiated mass fixed in space. Since the particles of $\mathrm{U}_{3} \mathrm{O}_{8}$ are being transported by the macrophages while they irradiate, the computed values are accurate only in the assumption that the actual time spent by the particles migrating inside the macrophages is negligible compared to the effective transport mean time $\lambda_{a}^{-1}$. Values of $\psi_{z}, D_{z}$, and $\left\langle D_{z}\right\rangle$ are reported as functions of $r_{0}$ and $t$ in Tables 4 and 5-7 for the lungs and lymph node compartments. From the time-dependent plots of $\left\langle D_{x}\right\rangle$ and $\left\langle D_{y}\right\rangle$ shown in Fig. 4, we can see that the dose delivered to the lungs by $1 \mu \mathrm{m}$ particles rises sharply and levels off after $\sim 10 \mathrm{yr}$ at a maximum of $\sim 0.11 \mathrm{~Gy}$, while the corresponding averaged specific dose delivered to the lymph nodes reaches $0.14 \mathrm{~Gy}$ and is still increasing even $30 \mathrm{yr}$ after the exposure. The averaged doses delivered to the two compartments are comparable, with the dose to the first compartment, being the location of the initial intake, dominating for the first $15 \mathrm{yr}$. The absorbed dose (albeit by a small mass of tissue, as made clear by the data in Tables 2-3) may be divided by the total initial mass of ${ }^{238} \mathrm{U}_{3} \mathrm{O}_{8}$ to obtain, $20 \mathrm{yr}$ after the intake of $2 \mu \mathrm{m}$ particles, the dose conversion factors 55.0 and $65.1 \mathrm{~Gy} \mathrm{mg}^{-1}$ for the lungs and lymph nodes, respectively. For the homogeneous system the corresponding value reported by Bem and Bou-Rabee ${ }^{(11)}$ is $1.2 \times 10^{-4} \mathrm{~Sv} \mathrm{mg}{ }^{-1}$. The wide separation between these two conversion factors summarizes the difference between the homogeneous and the non-homogeneous system. The $13.153 \mu \mathrm{g}$ intake of DU might seem negligible compared both to the average content in the human body of $56 \mu \mathrm{g}$ and the annual intake of $460 \mu \mathrm{g}$ by ingestion of food and water ${ }^{(6)}$, but if the radionuclide is concentrated in particles its radiation only targets a small mass of tissue for an extended period of time.

The $\alpha$ particles have also been shown to possess a specific action on DNA, and considerable chemical toxicity comes from the various chemical forms of uranium ${ }^{15}$ as well. As a crude approximation to the chemical damage to which the irradiated masses $M_{x}$ and $M_{y}$ are subjected, we may estimate the rate of unspecific bond breaking per cell $\dot{B}_{z}$ in the two compartments multiplying $\psi_{z}$ by the factor $N_{A} /\left(E_{\text {bond }} \rho_{c}\right)$ and assuming $E_{\text {bond }}=494.4 \mathrm{~kJ} \mathrm{~mol}^{-1}$, the $\mathrm{O}-\mathrm{H}$ binding energy of water. Similarly, the number of broken chemical bonds $B$ are obtained multiplying $\left\langle D_{z}\right\rangle$ by the same factor. For convenience, values of $\dot{B}_{z}$ are reported as functions of $r$ and $t$ in Table 8. From the 
column $\left(\dot{B}_{z}\right)_{t=0}$ in Table 1 we see that the rate of bond breaking per cell range from $\sim 10^{3}$ to $\sim 10^{5}$ $\mathrm{d}^{-1}$ for particles sized from 0.4 to $2.0 \mu \mathrm{m}$. It is worth stressing that it is immaterial whether the emitted $\alpha$ particles directly damage chemical bonds of biological significance or deliver their energy to water with formation of hydroxyl radicals $\mathrm{HO}$ and $\mathrm{H}_{2} \mathrm{O}^{++}$radical cations because these reactive species are able to rapidly diffuse to the regions of the cell containing the genetic material.

\section{CONCLUSION}

The limited range in tissue of alpha particles emitted by ${ }^{238} \mathrm{U}$ considerably reduces the actual mass subjected to irradiation by ceramic particles of ${ }^{238} \mathrm{U}_{3} \mathrm{O}_{8}$. Once this effect is taken into account in evaluating both the dose rate and the cumulative dose delivered to the affected tissues, 20 years after the exposure the averaged dose for $0.4 \leq r_{0} \leq 2.0 \mu \mathrm{m}$ ranges from $6.8 \mathrm{mGy}$ to $0.85 \mathrm{~Gy}$ for the lungs and from $8.1 \mathrm{mGy}$ to $1.01 \mathrm{~Gy}$ for the lymph nodes. However, the body mass affected by the radiation is only a fraction of a gram and rapidly decreases with the third power of particle size.

\section{ACKNOWLEDGEMENT}

The author wishes to thank an anonymous reviewer for the significant contribution toward making this a better paper. 
Figure 1. Fraction of the initial mass of $\mathrm{U}_{3} \mathrm{O}_{8}$ distributing into the two compartments following intake versus time.

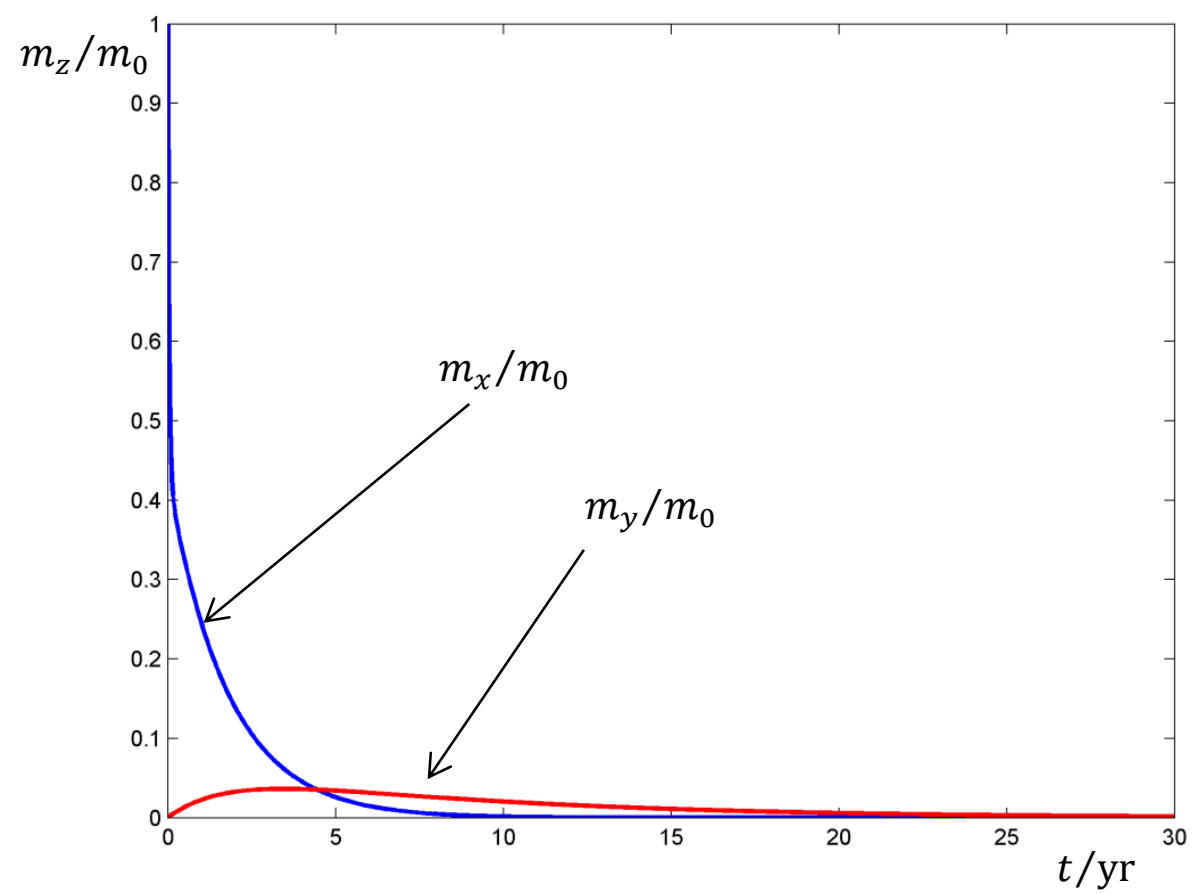

Figure 2. Fraction of the number of particles $N_{z} / N_{0}$ in the two compartments versus time.

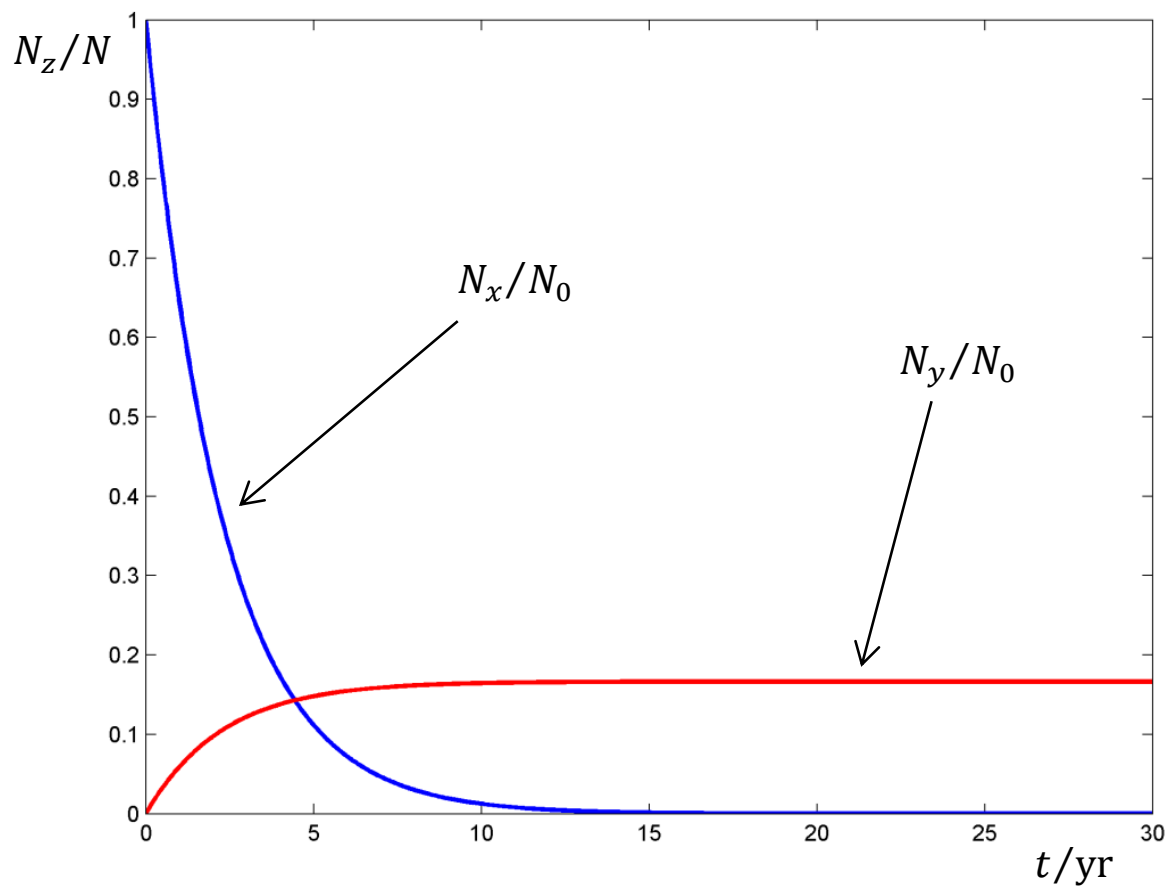


Figure 3. Plot of the dose rate $\psi_{z} / \mathrm{Gy} \mathrm{d}^{-1}$ delivered by $\mathrm{U}_{3} \mathrm{O}_{8}$ particles with $r_{0}=1 \mu \mathrm{m}$ to the two compartments $(z=x, y)$ versus time.

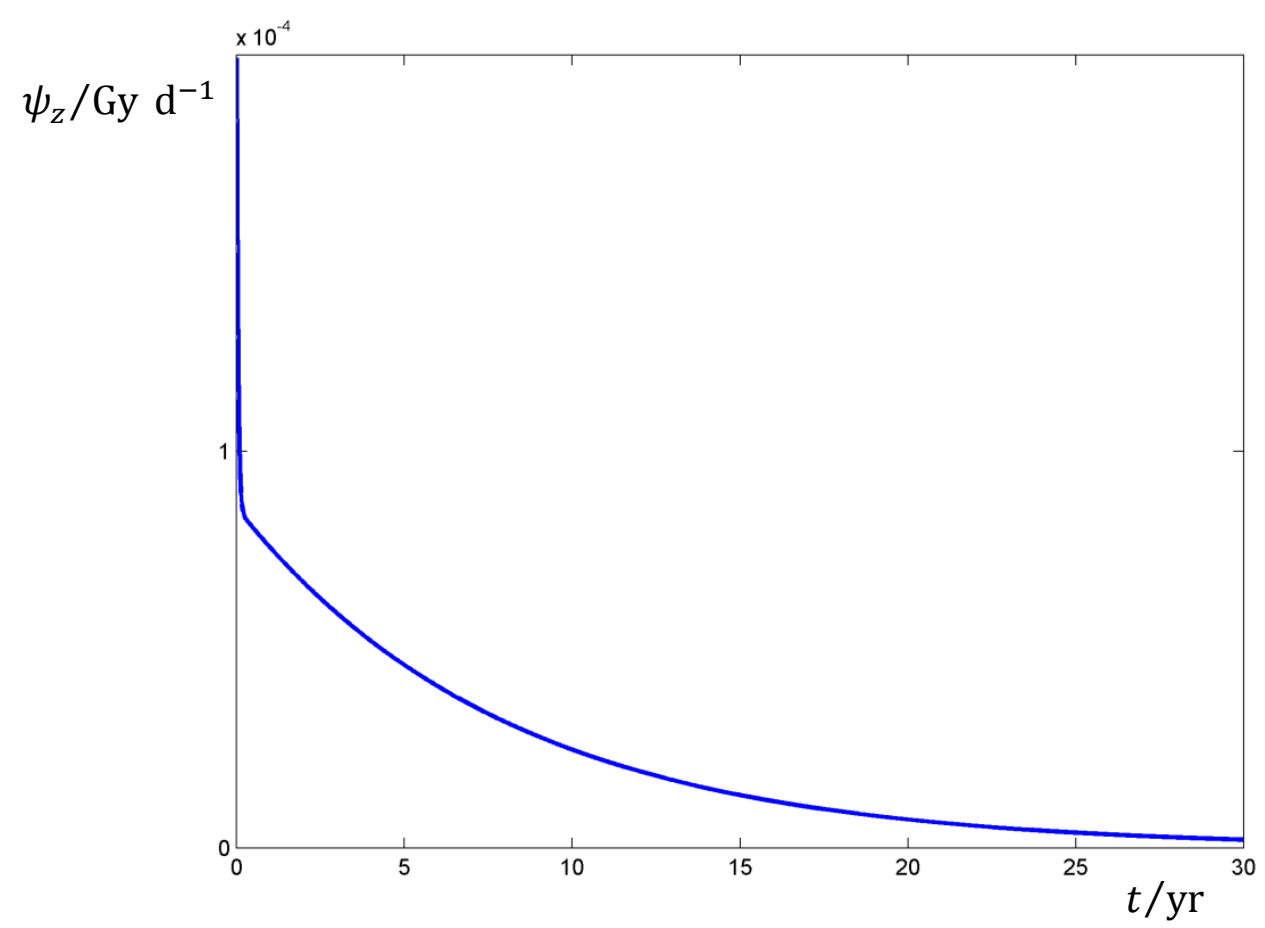

Figure 4. Plot of the dose $D_{z} /$ Gy and the averaged dose $<D_{z}>/$ Gy delivered by $\mathrm{U}_{3} \mathrm{O}_{8}$ particles with $r_{0}=1 \mu \mathrm{m}$ to the two compartments $(z=x, y)$ versus time.

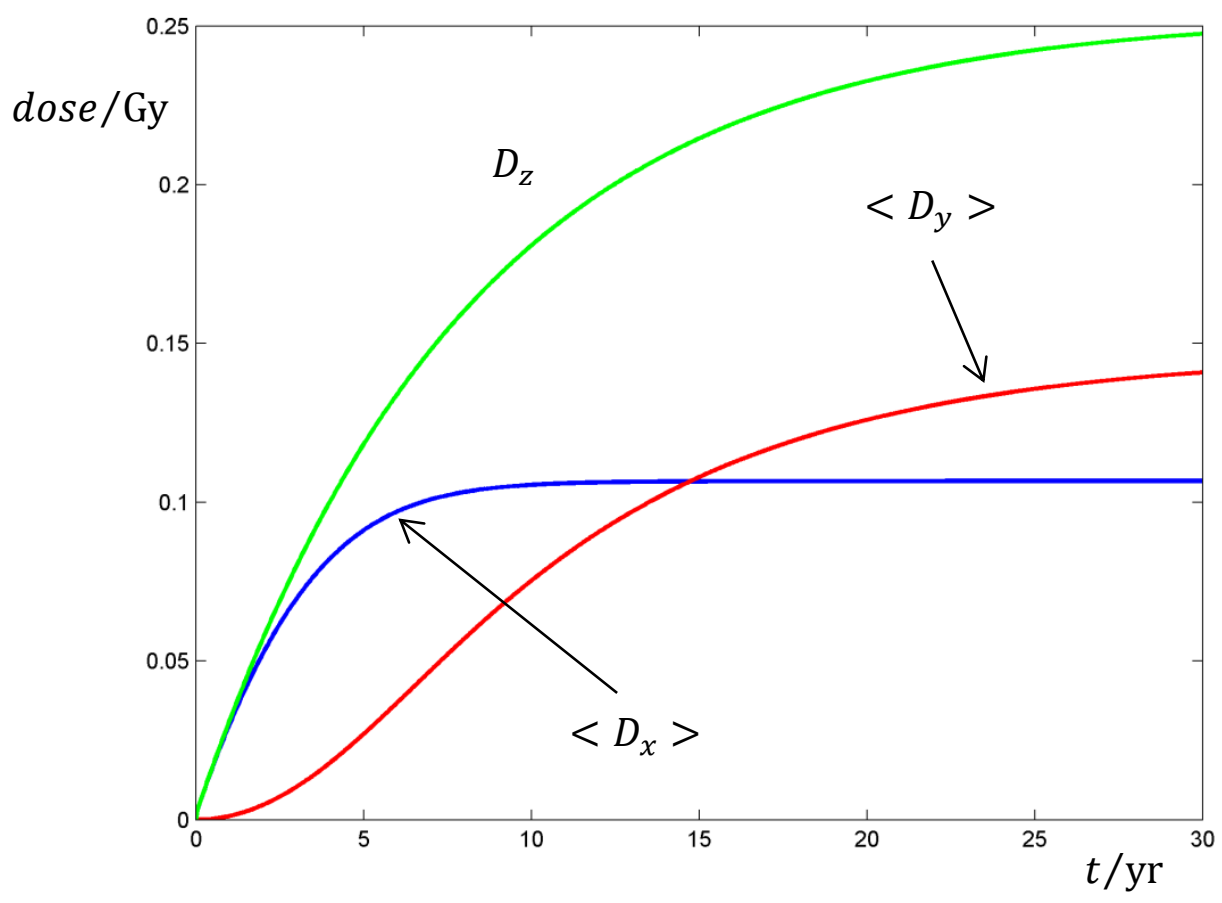


Table 1. Initial number of particles $N_{0}$ of radius $r_{0}$ in $15.51 \mu \mathrm{g}$ of $\mathrm{U}_{3} \mathrm{O}_{8}$, the estimated number of affected cells, the initial dose rate, and the initial rate of bond breaking.

\begin{tabular}{ccccc}
\hline$r_{0} / \mu \mathrm{m}$ & $N_{0}$ & cells & $\psi_{0} / \mathrm{Gy} \mathrm{d}^{-1}$ & $\left(\dot{B}_{z}\right)_{t=0} / \mathrm{d}^{-1}$ \\
\hline 0.4 & $6.95 \mathrm{E}+06$ & $1.08 \mathrm{E}+07$ & $1.28 \mathrm{E}-05$ & $1.09 \mathrm{E}+03$ \\
0.6 & $2.06 \mathrm{E}+06$ & $3.20 \mathrm{E}+06$ & $4.30 \mathrm{E}-05$ & $3.68 \mathrm{E}+03$ \\
0.8 & $8.68 \mathrm{E}+05$ & $1.35 \mathrm{E}+06$ & $1.02 \mathrm{E}-04$ & $8.72 \mathrm{E}+03$ \\
1.0 & $4.45 \mathrm{E}+05$ & $6.92 \mathrm{E}+05$ & $1.99 \mathrm{E}-04$ & $1.70 \mathrm{E}+04$ \\
1.2 & $2.57 \mathrm{E}+05$ & $4.01 \mathrm{E}+05$ & $3.44 \mathrm{E}-04$ & $2.94 \mathrm{E}+04$ \\
1.4 & $1.62 \mathrm{E}+05$ & $2.52 \mathrm{E}+05$ & $5.47 \mathrm{E}-04$ & $4.67 \mathrm{E}+04$ \\
1.6 & $1.09 \mathrm{E}+05$ & $1.69 \mathrm{E}+05$ & $8.16 \mathrm{E}-04$ & $6.97 \mathrm{E}+04$ \\
1.8 & $7.62 \mathrm{E}+04$ & $1.19 \mathrm{E}+05$ & $1.16 \mathrm{E}-03$ & $9.93 \mathrm{E}+04$ \\
2.0 & $5.56 \mathrm{E}+04$ & $8.65 \mathrm{E}+04$ & $1.59 \mathrm{E}-03$ & $1.36 \mathrm{E}+05$ \\
\hline
\end{tabular}

Table 2. Irradiated mass of the lungs $M_{x} / \mathrm{g}$ following intake of $15.51 \mu \mathrm{g}$ of $\mathrm{U}_{3} \mathrm{O}_{8}$ particles of initial radius $r_{0}$ at various times after the exposure.

\begin{tabular}{ccccc}
\hline$r_{0} / \mu \mathrm{m}$ & $1 \mathrm{yr}$ & $5 \mathrm{yr}$ & $10 \mathrm{yr}$ & $20 \mathrm{yr}$ \\
\hline 0.4 & $4.88 \mathrm{E}-01$ & $8.46 \mathrm{E}-02$ & $9.46 \mathrm{E}-03$ & $1.18 \mathrm{E}-04$ \\
0.6 & $1.45 \mathrm{E}-01$ & $2.51 \mathrm{E}-02$ & $2.80 \mathrm{E}-03$ & $3.50 \mathrm{E}-05$ \\
0.8 & $6.11 \mathrm{E}-02$ & $1.06 \mathrm{E}-02$ & $1.18 \mathrm{E}-03$ & $1.48 \mathrm{E}-05$ \\
1.0 & $3.13 \mathrm{E}-02$ & $5.42 \mathrm{E}-03$ & $6.05 \mathrm{E}-04$ & $7.56 \mathrm{E}-06$ \\
1.2 & $1.81 \mathrm{E}-02$ & $3.13 \mathrm{E}-03$ & $3.50 \mathrm{E}-04$ & $4.37 \mathrm{E}-06$ \\
1.4 & $1.14 \mathrm{E}-02$ & $1.97 \mathrm{E}-03$ & $2.21 \mathrm{E}-04$ & $2.75 \mathrm{E}-06$ \\
1.6 & $7.63 \mathrm{E}-03$ & $1.32 \mathrm{E}-03$ & $1.48 \mathrm{E}-04$ & $1.85 \mathrm{E}-06$ \\
1.8 & $5.36 \mathrm{E}-03$ & $9.29 \mathrm{E}-04$ & $1.04 \mathrm{E}-04$ & $1.30 \mathrm{E}-06$ \\
2.0 & $3.91 \mathrm{E}-03$ & $6.77 \mathrm{E}-04$ & $7.57 \mathrm{E}-05$ & $9.45 \mathrm{E}-07$ \\
\hline
\end{tabular}

Table 3. Irradiated mass in the lymph nodes $M_{y} / \mathrm{g}$ following intake of $15.51 \mu \mathrm{g}$ of $\mathrm{U}_{3} \mathrm{O}_{8}$ particles of initial radius $r_{0}$ at various times after the exposure.

\begin{tabular}{ccccc}
\hline$r_{0} / \mu \mathrm{m}$ & $1 \mathrm{yr}$ & $5 \mathrm{yr}$ & $10 \mathrm{yr}$ & $20 \mathrm{yr}$ \\
\hline 0.4 & $4.48 \mathrm{E}-02$ & $1.12 \mathrm{E}-01$ & $1.25 \mathrm{E}-01$ & $1.26 \mathrm{E}-01$ \\
0.6 & $1.33 \mathrm{E}-02$ & $3.32 \mathrm{E}-02$ & $3.69 \mathrm{E}-02$ & $3.74 \mathrm{E}-02$ \\
0.8 & $5.60 \mathrm{E}-03$ & $1.40 \mathrm{E}-02$ & $1.56 \mathrm{E}-02$ & $1.58 \mathrm{E}-02$ \\
1.0 & $2.87 \mathrm{E}-03$ & $7.17 \mathrm{E}-03$ & $7.97 \mathrm{E}-03$ & $8.07 \mathrm{E}-03$ \\
1.2 & $1.66 \mathrm{E}-03$ & $4.15 \mathrm{E}-03$ & $4.61 \mathrm{E}-03$ & $4.67 \mathrm{E}-03$ \\
1.4 & $1.04 \mathrm{E}-03$ & $2.61 \mathrm{E}-03$ & $2.91 \mathrm{E}-03$ & $2.94 \mathrm{E}-03$ \\
1.6 & $7.00 \mathrm{E}-04$ & $1.75 \mathrm{E}-03$ & $1.95 \mathrm{E}-03$ & $1.97 \mathrm{E}-03$ \\
1.8 & $4.91 \mathrm{E}-04$ & $1.23 \mathrm{E}-03$ & $1.37 \mathrm{E}-03$ & $1.38 \mathrm{E}-03$ \\
2.0 & $3.58 \mathrm{E}-04$ & $8.97 \mathrm{E}-04$ & $9.97 \mathrm{E}-04$ & $1.01 \mathrm{E}-03$ \\
\hline
\end{tabular}


Table 4. Dose rate $\psi_{z}\left(\mathrm{~Gy} \mathrm{~d}^{-1}\right)$ delivered to a mass $M$ of the lungs and lymph nodes upon intake of $15.51 \mu \mathrm{g}$ of $\mathrm{U}_{3} \mathrm{O}_{8}$ particles of initial radius $r_{0}$ at various times after the exposure.

\begin{tabular}{ccccc}
\hline$r_{0} / \mu \mathrm{m}$ & $1 \mathrm{yr}$ & $5 \mathrm{yr}$ & $10 \mathrm{yr}$ & $20 \mathrm{yr}$ \\
\hline 0.4 & $4.84 \mathrm{E}-06$ & $2.95 \mathrm{E}-06$ & $1.58 \mathrm{E}-06$ & $4.58 \mathrm{E}-07$ \\
0.6 & $1.63 \mathrm{E}-05$ & $9.95 \mathrm{E}-06$ & $5.35 \mathrm{E}-06$ & $1.54 \mathrm{E}-06$ \\
0.8 & $3.87 \mathrm{E}-05$ & $2.36 \mathrm{E}-05$ & $1.27 \mathrm{E}-05$ & $3.66 \mathrm{E}-06$ \\
1.0 & $7.57 \mathrm{E}-05$ & $4.61 \mathrm{E}-05$ & $2.48 \mathrm{E}-05$ & $7.15 \mathrm{E}-06$ \\
1.2 & $1.31 \mathrm{E}-04$ & $7.96 \mathrm{E}-05$ & $4.28 \mathrm{E}-05$ & $1.24 \mathrm{E}-05$ \\
1.4 & $2.08 \mathrm{E}-04$ & $1.26 \mathrm{E}-04$ & $6.79 \mathrm{E}-05$ & $1.96 \mathrm{E}-05$ \\
1.6 & $3.10 \mathrm{E}-04$ & $1.89 \mathrm{E}-04$ & $1.01 \mathrm{E}-04$ & $2.93 \mathrm{E}-05$ \\
1.8 & $4.41 \mathrm{E}-04$ & $2.69 \mathrm{E}-04$ & $1.44 \mathrm{E}-04$ & $4.17 \mathrm{E}-05$ \\
2.0 & $6.05 \mathrm{E}-04$ & $3.68 \mathrm{E}-04$ & $1.98 \mathrm{E}-04$ & $5.72 \mathrm{E}-05$ \\
\hline
\end{tabular}

Table 5. Dose $D_{z}$ (Gy) absorbed by a mass $M$ of the lungs and lymph nodes upon intake of $15.51 \mu \mathrm{g}$ of $\mathrm{U}_{3} \mathrm{O}_{8}$ particles of initial radius $r_{0}$ at various times after the exposure.

\begin{tabular}{ccccc}
\hline$r_{0} / \mu \mathrm{m}$ & $1 \mathrm{yr}$ & $5 \mathrm{yr}$ & $10 \mathrm{yr}$ & $20 \mathrm{yr}$ \\
\hline 0.4 & $1.99 \mathrm{E}-03$ & $7.56 \mathrm{E}-03$ & $1.16 \mathrm{E}-02$ & $1.49 \mathrm{E}-02$ \\
0.6 & $6.71 \mathrm{E}-03$ & $2.55 \mathrm{E}-02$ & $3.91 \mathrm{E}-02$ & $5.02 \mathrm{E}-02$ \\
0.8 & $1.59 \mathrm{E}-02$ & $6.05 \mathrm{E}-02$ & $9.26 \mathrm{E}-02$ & $1.19 \mathrm{E}-01$ \\
1.0 & $3.11 \mathrm{E}-02$ & $1.18 \mathrm{E}-01$ & $1.81 \mathrm{E}-01$ & $2.33 \mathrm{E}-01$ \\
1.2 & $5.37 \mathrm{E}-02$ & $2.04 \mathrm{E}-01$ & $3.13 \mathrm{E}-01$ & $4.02 \mathrm{E}-01$ \\
1.4 & $8.52 \mathrm{E}-02$ & $3.24 \mathrm{E}-01$ & $4.96 \mathrm{E}-01$ & $6.38 \mathrm{E}-01$ \\
1.6 & $1.27 \mathrm{E}-01$ & $4.84 \mathrm{E}-01$ & $7.41 \mathrm{E}-01$ & $9.53 \mathrm{E}-01$ \\
1.8 & $1.81 \mathrm{E}-01$ & $6.89 \mathrm{E}-01$ & $1.05 \mathrm{E}+00$ & $1.36 \mathrm{E}+00$ \\
2.0 & $2.48 \mathrm{E}-01$ & $9.46 \mathrm{E}-01$ & $1.45 \mathrm{E}+00$ & $1.86 \mathrm{E}+00$ \\
\hline
\end{tabular}

Table 6. Averaged dose $\left\langle D_{x}\right\rangle /$ Gy absorbed by a mass $M_{x}$ of the lungs upon intake of $15.51 \mu \mathrm{g}$ of $\mathrm{U}_{3} \mathrm{O}_{8}$ particles of initial radius $r_{0}$ at various times after the exposure.

\begin{tabular}{ccccc}
\hline$r_{0} / \mu \mathrm{m}$ & $1 \mathrm{yr}$ & $5 \mathrm{yr}$ & $10 \mathrm{yr}$ & $20 \mathrm{yr}$ \\
\hline 0.4 & $1.91 \mathrm{E}-03$ & $5.83 \mathrm{E}-03$ & $6.75 \mathrm{E}-03$ & $6.83 \mathrm{E}-03$ \\
0.6 & $6.46 \mathrm{E}-03$ & $1.97 \mathrm{E}-02$ & $2.28 \mathrm{E}-02$ & $2.30 \mathrm{E}-02$ \\
0.8 & $1.53 \mathrm{E}-02$ & $4.67 \mathrm{E}-02$ & $5.40 \mathrm{E}-02$ & $5.46 \mathrm{E}-02$ \\
1.0 & $2.99 \mathrm{E}-02$ & $9.12 \mathrm{E}-02$ & $1.05 \mathrm{E}-01$ & $1.07 \mathrm{E}-01$ \\
1.2 & $5.17 \mathrm{E}-02$ & $1.58 \mathrm{E}-01$ & $1.82 \mathrm{E}-01$ & $1.84 \mathrm{E}-01$ \\
1.4 & $8.20 \mathrm{E}-02$ & $2.50 \mathrm{E}-01$ & $2.89 \mathrm{E}-01$ & $2.93 \mathrm{E}-01$ \\
1.6 & $1.22 \mathrm{E}-01$ & $3.73 \mathrm{E}-01$ & $4.32 \mathrm{E}-01$ & $4.37 \mathrm{E}-01$ \\
1.8 & $1.74 \mathrm{E}-01$ & $5.32 \mathrm{E}-01$ & $6.15 \mathrm{E}-01$ & $6.22 \mathrm{E}-01$ \\
2.0 & $2.39 \mathrm{E}-01$ & $7.29 \mathrm{E}-01$ & $8.44 \mathrm{E}-01$ & $8.53 \mathrm{E}-01$ \\
\hline
\end{tabular}


Table 7. Averaged dose $<D_{y}>/$ Gy absorbed by a mass $M_{y}$ of the lymph nodes upon intake of $15.51 \mu \mathrm{g}$ of $\mathrm{U}_{3} \mathrm{O}_{8}$ particles of initial radius $r_{0}$ at various times after the exposure.

\begin{tabular}{ccccc}
\hline$r_{0} / \mu \mathrm{m}$ & $1 \mathrm{yr}$ & $5 \mathrm{yr}$ & $10 \mathrm{yr}$ & $20 \mathrm{yr}$ \\
\hline 0.4 & $7.43 \mathrm{E}-05$ & $1.73 \mathrm{E}-03$ & $4.82 \mathrm{E}-03$ & $8.06 \mathrm{E}-03$ \\
0.6 & $2.51 \mathrm{E}-04$ & $5.84 \mathrm{E}-03$ & $1.63 \mathrm{E}-02$ & $2.72 \mathrm{E}-02$ \\
0.8 & $5.94 \mathrm{E}-04$ & $1.38 \mathrm{E}-02$ & $3.86 \mathrm{E}-02$ & $6.45 \mathrm{E}-02$ \\
1.0 & $1.16 \mathrm{E}-03$ & $2.70 \mathrm{E}-02$ & $7.54 \mathrm{E}-02$ & $1.26 \mathrm{E}-01$ \\
1.2 & $2.01 \mathrm{E}-03$ & $4.67 \mathrm{E}-02$ & $1.30 \mathrm{E}-01$ & $2.18 \mathrm{E}-01$ \\
1.4 & $3.19 \mathrm{E}-03$ & $7.42 \mathrm{E}-02$ & $2.07 \mathrm{E}-01$ & $3.46 \mathrm{E}-01$ \\
1.6 & $4.75 \mathrm{E}-03$ & $1.11 \mathrm{E}-01$ & $3.09 \mathrm{E}-01$ & $5.16 \mathrm{E}-01$ \\
1.8 & $6.77 \mathrm{E}-03$ & $1.58 \mathrm{E}-01$ & $4.40 \mathrm{E}-01$ & $7.35 \mathrm{E}-01$ \\
2.0 & $9.29 \mathrm{E}-03$ & $2.16 \mathrm{E}-01$ & $6.03 \mathrm{E}-01$ & $1.01 \mathrm{E}+00$ \\
\hline
\end{tabular}

Table 8. Rate of bond breaking per affected cell $\dot{B}_{z} / \mathrm{d}^{-1}$ in the lungs and lymph nodes caused by the radiation delivered by $15.51 \mu \mathrm{g}$ of $\mathrm{U}_{3} \mathrm{O}_{8}$ particles of initial radius $r_{0}$ to the mass $M$ of tissue at various times after the exposure.

\begin{tabular}{ccccc}
\hline$r_{0} / \mu \mathrm{m}$ & $1 \mathrm{yr}$ & $5 \mathrm{yr}$ & $10 \mathrm{yr}$ & $20 \mathrm{yr}$ \\
\hline 0.4 & $4.14 \mathrm{E}+02$ & $2.52 \mathrm{E}+02$ & $1.35 \mathrm{E}+02$ & $3.91 \mathrm{E}+01$ \\
0.6 & $1.40 \mathrm{E}+03$ & $8.50 \mathrm{E}+02$ & $4.57 \mathrm{E}+02$ & $1.32 \mathrm{E}+02$ \\
0.8 & $3.31 \mathrm{E}+03$ & $2.01 \mathrm{E}+03$ & $1.08 \mathrm{E}+03$ & $3.13 \mathrm{E}+02$ \\
1.0 & $6.47 \mathrm{E}+03$ & $3.93 \mathrm{E}+03$ & $2.11 \mathrm{E}+03$ & $6.11 \mathrm{E}+02$ \\
1.2 & $1.12 \mathrm{E}+04$ & $6.80 \mathrm{E}+03$ & $3.65 \mathrm{E}+03$ & $1.06 \mathrm{E}+03$ \\
1.4 & $1.77 \mathrm{E}+04$ & $1.08 \mathrm{E}+04$ & $5.80 \mathrm{E}+03$ & $1.68 \mathrm{E}+03$ \\
1.6 & $2.65 \mathrm{E}+04$ & $1.61 \mathrm{E}+04$ & $8.66 \mathrm{E}+03$ & $2.50 \mathrm{E}+03$ \\
1.8 & $3.77 \mathrm{E}+04$ & $2.29 \mathrm{E}+04$ & $1.23 \mathrm{E}+04$ & $3.56 \mathrm{E}+03$ \\
2.0 & $5.17 \mathrm{E}+04$ & $3.15 \mathrm{E}+04$ & $1.69 \mathrm{E}+04$ & $4.89 \mathrm{E}+03$ \\
\hline
\end{tabular}




\section{REFERENCES}

1. Lind, O.C., Salbu, B., Skipperud, L., Janssens, K., Jaroszewicz, J. and De Nolf, W. Solid state speciation and potential bioavailability of depleted uranium particles from Kosovo and Kuwait. Journal of Environmental Radioactivity 100, 301-307 (2009).

2. Miller, A.C., Bonait-Pellie, C., Merlot, R.F., Michel, J., Stewart, M. and Lison, P.D. Leukemic transformation of hematopoietic cells in mice internally exposed to depleted uranium. Molecular and Cellular Biochemistry 279, 97-104 (2005).

3. Miller, A.C. and McClain, D. A Review of Depleted Uranium Biological Effects: In Vitro and In Vivo Studies. Reviews on Environmental Health 22, 75-89 (2007).

4. Bland, D., Rona, R., Coggon, D., Anderson, J., Greenberg, N., Hull, L. and Wessely, S. Urinary isotopic analysis in the UK Armed Forces: no evidence of depleted uranium absorption in combat and other personnel in Iraq. Occupational and Environmental Medicine 64, 834-838 (2007).

5. Busby, C., Hamdan, M. and Ariabi, E. Cancer, Infant Mortality and Birth Sex-Ratio in Fallujah, Iraq 2005-2009. Int. J. Environ. Res. Public Health 7, 2828-2837 (2010).

6. Bleise, A., Danesi, P.R. and Burkart, W. Properties, use and health effects of depleted uranium (DU): a general overview. Journal of Environmental Radioactivity 64, 93-112 (2003).

7. Chazel, V., Gerasimo, P., Dabouis, V., Laroche, P. and Paquet, F. Characterisation and dissolution of depleted uranium aerosols produced during impacts of kinetic energy penetrators against a tank. Radiation Protection Dosimetry 105, 163-166 (2003).

8. Durante, M. and Pugliese, M. Depleted uranium residual radiological risk assessment for Kosovo sites. Journal of Environmental Radioactivity 64, 237-245 (2003).

9. Uijt de Haag, P.A.M., Smetsers, R.C.G.M., Witlox, H.W.M., Krüs, H.W. and Eisenga, A.H.M. Evaluating the risk from depleted uranium after the Boeing 747-258F crash in Amsterdam, 1992. Journal of Hazardous Materials A76, 39-58 (2000).

10. Valdés, M. Estimating the lung burden from exposure to aerosols of depleted uranium. Radiation Protection Dosimetry 134, 23-29 (2009).

11. Bem, H. and Bou-Rabee, F. Environmental and health consequences of depleted uranium use in the 1991 Gulf War. Environment International 30, 123-134 (2004).

12. ASTAR (NIST, National Institute of Standards and Technology): Stopping power and range tables for helium ions: http://physics.nist.gov/PhysRefData/Star/Text/ASTAR.html.

13. Poncy, J-L., Metivier, H., Dhilly, M., Verry, M. and Masse, R. In vitro dissolution of uranium oxide by baboon alveolar macrophages. Environmental Health Perspectives 97, 127-130 (1992).

14. Wrenn, M.E., Bertelli, L., Durbin, P.W., Singh, N.P., Lipsztein, J.L. and Eckerman, K.F. A Comprehensive Metabolic Model for Uranium Metabolism and Dosimetry Based on Human and Animal Data. Radiation Protection Dosimetry 53(1-4), 255-258 (1994).

15. Miller, A.C., Stewart, M., Brooks, K., Shi, L. and Page, N. Depleted uranium-catalyzed oxidative DNA damage: absence of significant alpha particle decay. Journal of Inorganic Biochemistry 91, 246-252 (2002). 